\title{
Molecular cloning, characterization and nucleotide sequence of the gene for secreted $\alpha$-amylase from Xanthomonas campestris pv. campestris
}

\author{
Nien-TaI Hu, ${ }^{1 *}$ Ming-Ni Hung, ${ }^{1,2}$ A-Min Huang, ${ }^{1,2} \dagger$ HuEI-Fung Tsai, ${ }^{1,2} \ddagger$ \\ BIH-YING YANG, ${ }^{1} \S$ TeH-YUAN CHOW $^{3}$ and YI-HsiUng TsENG ${ }^{2}$ \\ ${ }^{1,2}$ Agricultural Biotechnology Laboratories ${ }^{1}$ and Graduate Institute of Botany ${ }^{2}$, National Chung Hsing University, 250 \\ Kuo Kuang Road, Taichung, Taiwan 40227, Republic of China \\ ${ }^{3}$ Institute of Botany, Academia Sinica, Nankang, Taiwan, Republic of China
}

(Received 29 January 1992; revised 11 April 1992; accepted 30 April 1992)

\begin{abstract}
$\alpha$-Amylase (1,4- $\alpha$-D-glucan glucanohydrolase, EC 3.2.1.1) of apparent molecular mass $45 \mathrm{kDa}$ was secreted by Xanthomonas campestris pv. campestris grown in medium containing starch or maltose. We isolated its structural gene from a recombinant $\lambda$ library and located it on a $2.7 \mathrm{~kb}$ DNA fragment. Nucleotide sequencing of the fragment revealed a potential ORF encoding a protein of 475 amino acid residues, including a potential signal sequence of 35 amino acids. The signal processing site was confirmed by $\mathbf{N}$-terminal amino acid sequence analysis of the exported $\alpha$-amylase. The deduced amino acid sequence of the mature protein is very similar to that of the $\alpha$-amylase of Aeromonas hydrophila. It also contains all four amino acid sequences highly conserved in the $\alpha$ amylases from a wide range of organisms. Expression of the amy gene in Escherichia coli was poor from its own promoter, but was enhanced by the upstream promoter on the vector. The $\alpha$-amylase synthesized in $E$. coli was located in the periplasm.
\end{abstract}

\section{Introduction}

Extracellular proteins produced by Gram-negative bacteria have to traverse a cell envelope composed of two membranes. One of the unsolved problems is how these proteins are translocated across this complex barrier. Depending upon whether an $\mathrm{N}$-terminal signal sequence is present in the unprocessed exported proteins, they can be divided into two categories (Hirst \& Welch, 1988). Either genetic or biochemical evidence has been reported in different cases to suggest that a majority of the extracellular proteins with an $\mathrm{N}$-terminal signal sequence were exported via the periplasm (Andro et al., 1984; Hirst \& Holmgren, 1987; Howard \& Buckley, 1983). On the other hand, in the case of the haemolysin of Escherichia coli, no periplasmic intermediate was detect-

\footnotetext{
* Author for correspondence. Tel. 4287 4754; fax 42861905.

$\dagger$ Present address: Department of Pathology, School of Medicine, National Taiwan University, Taipai, Taiwan, Republic of China.

$\ddagger$ Present address: Department of Plant Pathology, University of Kentucky, Lexington, Kentucky, USA.

$\S$ Present address: Department of Biology, University of Maryland, Baltimore, Maryland, USA.

The nucleotide sequence data reported in this paper have been submitted to GenBank and have been assigned the accession number M32874.
}

ed in excretion mutants (Gray et al., 1986). Comparison of the $\mathrm{N}$-terminal amino acid sequence of the extracellular haemolysin with that of the amino acid sequence predicted from the nucleotide sequence of the gene indicated that the protein was exported without any processing at its $\mathrm{N}$-terminus (Felmlee et al., 1985). Instead, the signal required for export resides at the C-terminus (Gray et al., 1986). It was proposed that the haemolysin was exported through a haemolysin translocator at junctions between the inner and outer membranes (Holland et al., 1990).

Among other proteins (Daniels et al., 1984), an $\alpha$ amylase that hydrolyses starch endolytically at random (Tseng \& Peng, 1985) is exported into the milieu by the Gram-negative bacterium Xanthomonas campestris pv. campestris (Dow et al., 1987; Tseng \& Peng, 1985). Protein export mutants of $X$. campestris pv. campestris have been isolated by Dow et al. (1987) and from our laboratory (Hu et al., 1992). Accumulation of $\alpha$-amylase in the periplasm was observed in these mutants (Dow et al., 1987; Hu et al., 1992), suggesting that $\alpha$-amylase may be exported via the periplasm. In this study, the gene encoding the $\alpha$-amylase (amy) of $X$. campestris pv. campestris was cloned and sequenced. A probable $\mathrm{N}$ terminal signal sequence of 35 amino acid residues was predicted from the deduced amino acid sequence. 
Table 1. Bacterial strains and plasmids

\begin{tabular}{|c|c|c|}
\hline Strain or plasmid & Relevant characteristics & Source or reference \\
\hline \multicolumn{3}{|l|}{$X$. campestris pv. campestris } \\
\hline $\begin{array}{l}\mathrm{XC1701} \\
\text { E. coli }\end{array}$ & Rif $^{r}$ & Spontaneous mutant of $\mathrm{XC} 17^{*}$ \\
\hline \multicolumn{3}{|l|}{ E. coli } \\
\hline JM101 & $\begin{array}{l}\Delta(\text { lac-pro }) \text { supE thi } \mathrm{F}^{\prime}(\text { traD36 } \\
\left.\text { proAB lac } I^{q-Z} \Delta \mathrm{M} 15\right)\end{array}$ & Messing (1979) \\
\hline BHB2688 & $\begin{array}{l}\text { recA }(\operatorname{Eam} 4 \text { b2 red } 3 \text { imm } 434 \\
\text { cIts } \operatorname{Sam} 7)\end{array}$ & Hohn \& Murray (1977) \\
\hline BHB2690 & $\begin{array}{l}\operatorname{rec} A(\operatorname{Dam} 15 \text { b2 red } 3 \text { imm } 434 \\
\text { cIts } \operatorname{Sam} 7)\end{array}$ & Hohn \& Murray (1977) \\
\hline BNN45 & hsdR supE44 supF thi met & C.-H. Lee, Indiana University, USA. \\
\hline NM538 & supF hsdR trpR lacY & Frischauf et al. (1983) \\
\hline NM539 & supF hsdR lac $Y(\mathrm{P} 2 \cos 3)$ & Frischauf et al. (1983) \\
\hline pUC13 & $A p^{r}$ & Vieira \& Messing (1982) \\
\hline
\end{tabular}

* Bacterial strain obtained from S.-T. Hsu of National Chung Hsing University, Taiwan, Republic of China.

\section{Methods}

Bacterial strains and plasmids. The bacterial strains and plasmids used in this study are listed in Table 1.

Media. Luria broth (Miller, 1972) was used for culturing all the bacteria. Solid M9 medium (Miller, 1972), supplemented with thiamin $\left(10 \mu \mathrm{g} \mathrm{mi}^{-1}\right)$, was used for growing $E$. coli $\mathrm{JM} 101$. Minimal medium $\mathrm{XOL}\left[1^{-1}: 0.7 \mathrm{~g} \mathrm{~K}_{2} \mathrm{HPO}_{4}, 0.2 \mathrm{~g} \mathrm{KH}_{2} \mathrm{PO}_{4}, 1 \mathrm{~g}\left(\mathrm{NH}_{4}\right)_{2} \mathrm{SO}_{4}, 0.01 \mathrm{~g}\right.$ $\mathrm{FeSO}_{4} .7 \mathrm{H}_{2} \mathrm{O}, 0.001 \mathrm{~g} \mathrm{MnCl}_{2}, 0.1 \mathrm{~g} \mathrm{MgCl}_{2}, \mathrm{pH} 7 \cdot 15$ ] (Chu \& Tseng, 1981) supplemented with $0.125 \%$ tryptone, $0.125 \%$ yeast extract and $0.2 \%$ soluble starch was used for induction of $\alpha$-amylase production by $E$. coli or $X$. campestris pv. campestris. When soluble starch was included at $2 \%(\mathrm{w} / \mathrm{v})$ and kept at $4{ }^{\circ} \mathrm{C}$ till the medium turned opaque, starch hydrolysis could be detected directly as the clearing of the starch. Nozu supplement (Arber et al., 1983), comprising 0.3\% glucose, $7.5 \mu \mathrm{M}-\mathrm{CaCl}_{2}, 4 \mu \mathrm{M}-\mathrm{FeSO}_{4}$ and $2 \mathrm{mM}-\mathrm{MgSO}_{4}$, was included in Luria broth to raise the phage titre of the liquid lysate.

Construction of EMBL3 library of XC1701. Total DNA of XC1701 was partially digested with Sau3AI, treated with calf intestinal phosphatase and ligated with $\lambda E M B L 3$ DNA cleaved with $B a m H I$ and packaged in vitro with extracts prepared from the lysogens $E$. coli BHB2688 and $E$. coli BHB2690 (Silhavy et al., 1984). Infection of $E$. coli NM539 (Frischauf et al., 1983) with the packaged DNA yielded $1.2 \times 10^{4}$ p.f.u..

Transformation. The procedures of Cohen et al. (1972) for preparing $E$. coli competent cells and transformation were followed with slight modifications. Cells were treated with $100 \mathrm{mM}-\mathrm{CaCl}_{2}$ at $4{ }^{\circ} \mathrm{C}$ for 20 min. Ampicillin $\left(50 \mu \mathrm{g} \mathrm{ml}^{-1}\right)$ and tetracycline $\left(15 \mu \mathrm{g} \mathrm{ml}^{-1}\right)$ were used to select for plasmid transformants. Insertional inactivation of the lacZ gene on pUC13 was screened by including $50 \mu \mathrm{M}-\mathrm{IPTG}$ and $0.005 \%$ $\mathrm{X}$-Gal.

Cellular fractionation. The periplasmic fraction of $E$. coli was prepared as described by Neu \& Heppel (1965). For XC1701, the supernatant from centrifugation at $16000 \mathrm{~g}$ for $10 \mathrm{~min}$ was collected as the extracellular fraction. The pelleted cells were washed with distilled water twice, treated with lysozyme $(200 \mu \mathrm{g} \mathrm{ml})^{-1}$ in $20 \%(\mathrm{w} / \mathrm{v})$ sucrose$30 \mathrm{~mm}$-Tris/HCl, pH 8.0-1 mM-EDTA at $4{ }^{\circ} \mathrm{C}$ for $30 \mathrm{~min}$ and pelleted by centrifugation at $25000 \mathrm{~g}$ for $10 \mathrm{~min}$. The supernatant containing periplasmic materials was collected. The pelleted spheroplasts were broken by resuspending in $10 \mathrm{mM}-\mathrm{Tris} / \mathrm{HCl}, \mathrm{pH} 8.0$, and centrifuged at $25000 \mathrm{~g}$ for $15 \mathrm{~min}$ to collect the supernatant as the cytoplasmic fraction.

Enzyme assay. The extracellular, periplasmic or cytoplasmic fraction was incubated with $1 \%$ starch in $27.5 \mathrm{~mm}$-sodium/potassium phosphate buffer, $\mathrm{pH} 7.15$ at $37^{\circ} \mathrm{C}$, and the reducing sugar produced was determined according to the method of Nelson (1944). One unit of $\alpha$ amylase activity was defined as $1 \mu \mathrm{g}$ of glucose produced per min under these conditions.

SDS-PAGE and in situ activity stain. Extracellular proteins prepared from $30-40 \%$ ammonium sulphate precipitation were separated by SDS-PAGE on a $12 \%(\mathrm{w} / \mathrm{v})$ acrylamide gel. After electrophoresis, the gel was washed in $5 \mathrm{mM}$-potassium phosphate buffer, $\mathrm{pH} 7 \cdot 15$, twice at room temperature for $1 \mathrm{~h}$ each, and twice at $37^{\circ} \mathrm{C}$ for $80 \mathrm{~min}$ each (Tai et al., 1985). Detection of $\alpha$-amylase was performed by incubating the washed gel in $27.5 \mathrm{~mm}$-sodium/potassium phosphate buffer, $\mathrm{pH} 7.15$, containing $1 \%$ starch at $37^{\circ} \mathrm{C}$ for $2-4 \mathrm{~h}$, rinsing with water, blot drying and fumigating with iodine vapour. $\alpha$-Amylase activity appeared as a clear band against a blue background.

Nucleotide sequence determination and analysis. DNA sequences were determined using the dideoxy chain termination method of Sanger $e t a l$. (1977). Sequences of both strands were determined, either from M13 subclones or from deleted plasmids. Deletion of pB16 was accomplished with exonuclease III (ExolII) and S1 nuclease treatement (Henikoff, 1984). Sequences were analysed with Release 6.01 of PC/GENE (IntelliGenetics). Tfasta (Pearson \& Lipman, 1988) was used to search in the Genetics Computer Group (GCG) for homologous sequences.

$N$-Terminal amino acid sequence analysis of extracellular $\alpha$-amylase. The extracellular $\alpha$-amylase was prepared from an early stationary phase culture of the parental strain of $X$. campestris pv. campestris. Proteins collected from $30-40 \%$ ammonium sulphate precipitation were fractionated by DEAE-cellulose chromatography. The $\alpha$-amylase, whose activity appeared in the flow-through, was then concentrated followed by separation on an SDS-polyacrylamide gel. A $45 \mathrm{kDa}$ protein stained with Coomassie Blue (Fig. 1 $a$, upper band) coincided with the $\alpha$-amylase activity stain. After being electroblotted onto a polyvinylidene difluoride (PVDF) membrane, this $45 \mathrm{kDa}$ protein was analysed for its $\mathrm{N}$-terminal amino acid sequence using the Edman degradation method. 


\section{Results}

Characterization of the $\alpha$-amylase of $X$. campestris $p v$. campestris

$X$. campestris pv. campestris $\mathrm{XC} 1701$ was grown in $\mathrm{XOL}$ medium supplemented with $0 \cdot 2 \%$ starch to late exponential phase and the culture supernatant was fractionated using ammonium sulphate precipitation. The maximal starch-hydrolytic activity was obtained in the fraction precipitated with $30-40 \%$ ammonium sulphate, followed by that precipitated with $40-60 \%$ ammonium sulphate. HPLC analysis showed that the reaction products were glucose and maltose (not shown). Glucose constituted approximately $10 \%$ of the total product, suggesting that the starch was hydrolysed by an $\alpha$-amylase activity. Separation of the ammonium-sulphate-precipitated proteins on an SDS-polyacrylamide gel, followed by activity staining showed a major starch-hydrolysing activity with a molecular mass of $45 \mathrm{kDa}$ (Fig. 1).

\section{Isolation of the amy gene from an EMBL3 library}

A $\lambda$ EMBL3 library of XC1701 DNA was constructed and was plated out on a lawn of E. coli NM539 on starch medium. When the plaques were exposed to $I_{2}$ vapour, three out of approximately 300 plaques showed clear zones. These three recombinant phage, after plaque purification, were found to contain the same cloned DNA fragment. One of them was named Amyl and was studied further.

The restriction map of Amy1, which contains a cloned fragment of $15 \mathrm{~kb}$, is shown in Fig. 2(a). Different fragments (Fig. $2 b$ ) were subcloned into plasmid vectors and transformants assayed for enzymic activity. These experiments indicated that the amy gene was located on a $2.7 \mathrm{~kb} \mathrm{BamHI}$ fragment adjacent to the left arm of the $\lambda$ EMBL3 vector (Fig. $2 b$ ).

\section{Expression of the cloned amy gene in E. coli}

The Amy ${ }^{+}$subclone of Amyl, pB16 (Fig. 2b), contained a $2.7 \mathrm{~kb}$ BamHI fragment in pUC13. When the cloned fragment was reversed in its orientation with respect to the lac promoter on the vector, the starch-hydrolytic activity conferred to the $E$. coli host was significantly reduced, but not abolished. This suggested that the amy gene promoter might be recognized by the $E$. coli RNA polymerase. Nevertheless, expression of the amy gene was probably enhanced by the promoter located on the vector. Inclusion of IPTG caused a fivefold increase in the $\alpha$-amylase activity produced by JM101(pB16),

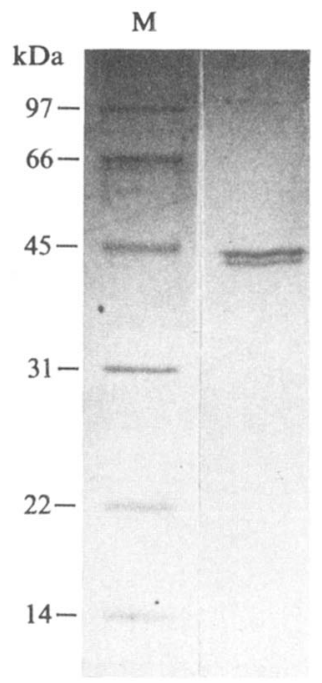

(a)

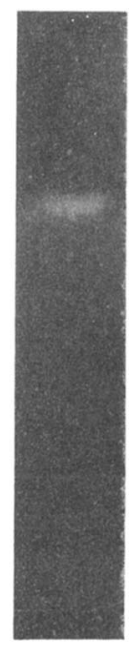

(b)
Fig. 1. Analysis of the $\alpha$-amylase prepared from XC1701 on a $12 \%$ SDS-polyacrylamide gel. Gel $(a)$ was stained with Coomassie Brilliant Blue; $(b)$ was stained in situ for starch hydrolytic activity following renaturation. The clear band in $(b)$ represents the area where starchhydrolytic enzyme activity migrated. Protein standards were included in the lane marked $\mathbf{M}$.

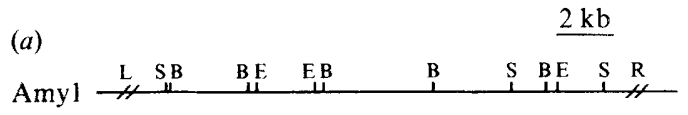

(b)

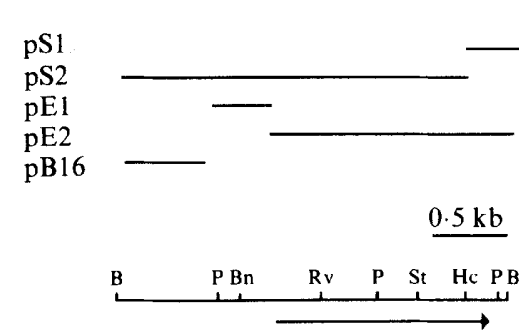

Fig. 2. (a) Restriction map of the recombinant phage Amyl. L and R represent the left and the right arms, respectively, of $\lambda E M B L 3 .(b)$ Subcloning experiment for locating the amy gene on Amy1. The fragments included in each subclone, shown as horizontal lines, are aligned with the restriction map of Amyl in $(a)$. (c) Restriction map of $\mathrm{pB} 16$. The ORF revealed by the sequencing data is represented by the arrow. Restriction sites are represented as follows: B, BamHI; E, EcoRI; S, SalI; Bn, BanII; Hc, HincII; P, PstI; RV, EcoRV; St, StuI.

indicating that the upstream lac promoter on $\mathrm{pB} 16$ might be responsible for the enhancement (data not shown). $\alpha$-Amylase synthesized in $E$. coli was found primarily in the periplasm, in contrast to that synthesized in $X$. campestris pv. campestris, which was secreted extracellularly (Table 2 ). 
CTGCTG GACGTCACGG CATCCATACC GGCAACCACC GCCGCCATTC ATCAGCACCG CGCGCAGTGC ATCGGTGCGA GTGCGACCGT GCACGCCCTC GGCATCGAAC CGGCCGCACG TTTCGCGGCT GTTGTGCAGT GAATACGTAI GCACAGGGTC AATGCTGCGC CGCGATGCGC GCIIAGCATC ACCGCGCGCC GCACGCCGTG

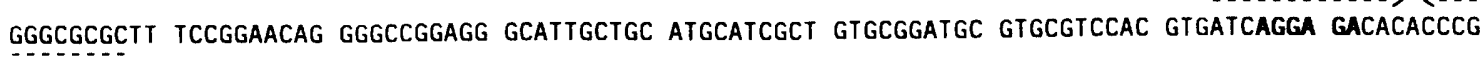
ATG CAC GCC ACC TCT CGC CCC TGT CCA CGC ACG TTC TGG CAA CGC GCT CAC CAG TTG CTG TTG ATC GCG CTG ACC ATG CAC GCC ACC TCT CGC CCC TGT CCA CGC ACG TTC TGG CAA CGC CCT CAC CAG TTG CTG TTG ATC GCG CTG ACC TTG TTG CTG ACC ACC GCC AGC GCA CAG GCC GAC GTC ATC CTG CAT GCG TTC AAC IGG CCC TAC GCC ACG GTA GAA

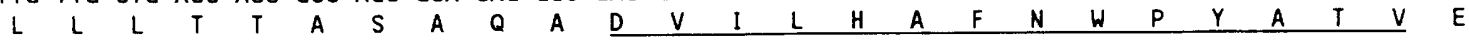
GCG CGC GCC AAG CAG ATC GCC GAT GCC GGG TAT CGC AAG GIA CTG GTC GCA CCG GCC TAT CGC TCC GAA GGC AGT $\begin{array}{lllllllllllllllllllllllll}A & R & A & K & 0 & I & A & D & A & G & Y & R & K & V & L & V & A & P & A & Y & R & S & E & G & S\end{array}$ GCC TGG TGG GCG CGC TAC CAG CCG CAG GAT ATC CGC CTG ATC GAC AAT CCA CTC GGC GAC ACC ACC GCG TTC GCG $\begin{array}{lllllllllllllllllllllllllll}A & W & W & A & R & Y & Q & P & Q & D & I & R & L & I & D & N & P & L & G & D & T & T & A & F & A & 100\end{array}$ CGC ATG GTG CAG GCA CTG GCA AAC AAC GGT GTG GAA ACC TAT GCC GAC GTG GTG TTC AAC CAC ATG GCC AAC GAA

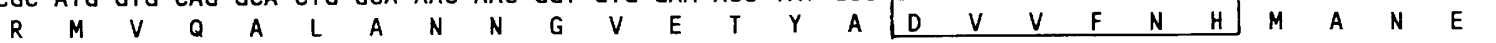
GCA GCA ACG CGC TCG GAC CTC AAT TAC CCC GGC AGC GCG GTG CTG GCG CAG TAC GCA GCC AAT CCT GGG CGC TAC $\begin{array}{llllllllllllllllllllllllll}A & A & T & R & S & D & L & N & Y & P & G & S & A & V & L & A & Q & Y & A & A & N & P & G & R & Y\end{array}$ GAT GCA CTG CGC CTG TTC GGC ACG GTG CAG TCC AAC TTT TTG AGC GCC AGT GAT TTC GGG CCG GCG CAA TGC ATC $\begin{array}{llllllllllllllllllllllllll}D & A & L & R & L & F & G & T & V & Q & S & N & F & L & S & A & S & D & F & G & P & A & Q & C & I & 175\end{array}$ AGC AAC TAC AAC GAT GCC TTC CAG GTG CGC AAT TAC CGC ATC TGC GGC GGC GGC AGC GAT CCG GGC CTG CCG GAT $\begin{array}{llllllllllllllllllllllllllll}S & N & Y & N & D & A & F & Q & V & R & N & Y & R & I & C & G & G & G & S & D & P & G & L & P & D & 200\end{array}$

CTG CTC GGC AAC GAT IGG GTG GTG CAG CAG CAG CGC GCC TAC CTG CAG GCG CTC AAG GGC CTG GGC GTC ACC GGC \begin{tabular}{llllllllllllllllllllllll}
$L$ & $L$ & $G$ & $N$ & $D$ & $W$ & $V$ & $V$ & $Q$ & $Q$ & $Q$ & $R$ & $A$ & $Y$ & $L$ & $Q$ & $A$ & $L$ & $K$ & $G$ & $L$ & $G$ & $V$ & $T$ \\
\hline
\end{tabular} Region 2

TTC CGC GTG GAC GCG GCC AAG CAC ATG ACC TTC GAC CAT CTC AAC CGC GTT TTC GAT GCC GGC ATC CGC ICC GGT $\left.\begin{array}{llllllllllllllllllllllllllll}F & R & V & D & A & A & K & H\end{array}\right]$ Region 3

GTG TAC GTG TTT GGT GAA GTG ATC ACC GGC GGT GGC AGC GGC AAT GGC GAC TAC GAC CAG TTC CTG GCG CCG TAT $\begin{array}{lllllllllllllllllllllllllll} & Y & V & F & G & E & V & I & T & G & G & G & S & G & N & G & D & Y & D & Q & F & L & A & P & Y\end{array}$

CTG CAA TCC ACC CCG CAT GCC GCC TAC GAT TTC CCG CTG ITC AAC GCG GTA CGC AAT GCC TTC GGT GTG GGT GCG

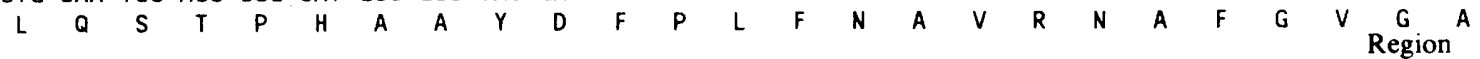
AGC ATG CAA CAG TTG GTG GAC CCG GCG TCC ACC GGG CAG GCC ITG CCG GGC AAT CGC GCA GTC ACC TTT GCC GTA \begin{tabular}{llllllllllllllllllllll|llll}
$S$ & $M$ & $Q$ & $Q$ & $L$ & $V$ & $D$ & $P$ & $A$ & $S$ & $T$ & $G$ & $Q$ & $A$ & $L$ & $P$ & $G$ & $N$ & $R$ & $A$ & $V$ & $T$ & $F$ & $A$ & $V$ \\
\hline
\end{tabular} $\frac{4}{\text { ACG CAT GAD ATC CCC AAT AAC GCG GGC ITC CGC TAC GCG ATT CTC GAC CCG GTC GAT GAA ACG CTG GCC TAT GCG }}$ $\begin{array}{lllllllllllllllllllllllll}I & H & D & I & P & N & N & A & G & F & R & Y & A & I & L & D & P & V & D & E & T & L & A & Y & A\end{array}$ TAC TTG CTG GGC CGC AAC GGC GGC GTG CCG ATG GTC TAC ACC GAC AAC AAC GAA AGC GGC GAC AAC CGC TGG GTC $\begin{array}{llllllllllllllllllllllllllll}Y & L & L & G & R & N & G & G & V & P & M & V & Y & T & D & N & N & E & S & G & D & N & R & W & V & 375\end{array}$ AAT GCC TAT CTG CGC GAT GAT CTG CGC CGC ATG ATT GGC TIC CAC AAC GGC GTG CAG GGC AGC GAC ATG CAG GTG $\begin{array}{lllllllllllllllllllllllllll}N & A & Y & L & R & D & D & L & R & R & M & I & G & F & H & N & G & V & Q & G & S & D & M & Q & V & 400\end{array}$ CTG TCA TCC AGT GCC TGC CAC ATC CTG TTC CGC CGC GGC AGC CTC GGC ATC GTG GGC ATC AAC AAG TGC GGC AAC $\begin{array}{lllllllllllllllllllllllll}L & S & S & S & A & C & H & I & L & F & R & R & G & S & L & G & I & V & G & I & N & K & C & G & N\end{array}$ CCG GTC AAC ACC ACC GTC GCC ATG AAC GGC AGC GTG ITG TTC TGG AAT GCG GAT TAC GTC GAT GCA CTG GGT TCC

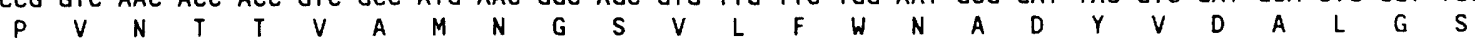
$\downarrow$

GGC ACC GTG GTG CGC ATC TCC AGT GGC TCG TAC ACC ITC ACC CTG CCG GCG CGG CAG GCG CGT ATG TGG CGA CGT

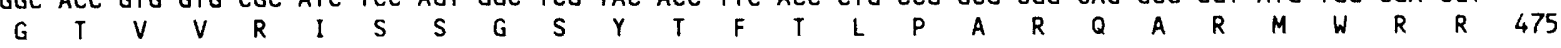

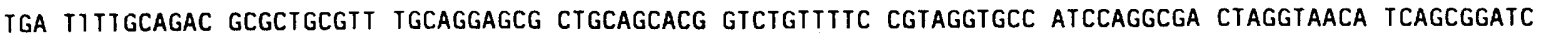

Fig. 3. Nucleotide sequence and deduced amino acid sequence of the amy gene of $X$. campestris pv. campestris. In the $5^{\prime}$ untranslated region, the potential -10 and -35 regions are in bold type and underlined. The potential ribosome-binding site is in bold type only. The dyad symmetrical structure of the putative operator is shown by the dashed arrows. In the translated region, the $\mathrm{N}$-terminal amino acid sequence determined from extracellular $\alpha$-amylase is underlined. Sequences highly conserved in other $\alpha$-amylases are boxed. A downward arrow near the C-terminus marks the left-hand position of the deletion mentioned in the text. The asterisk denotes a stop codon. 


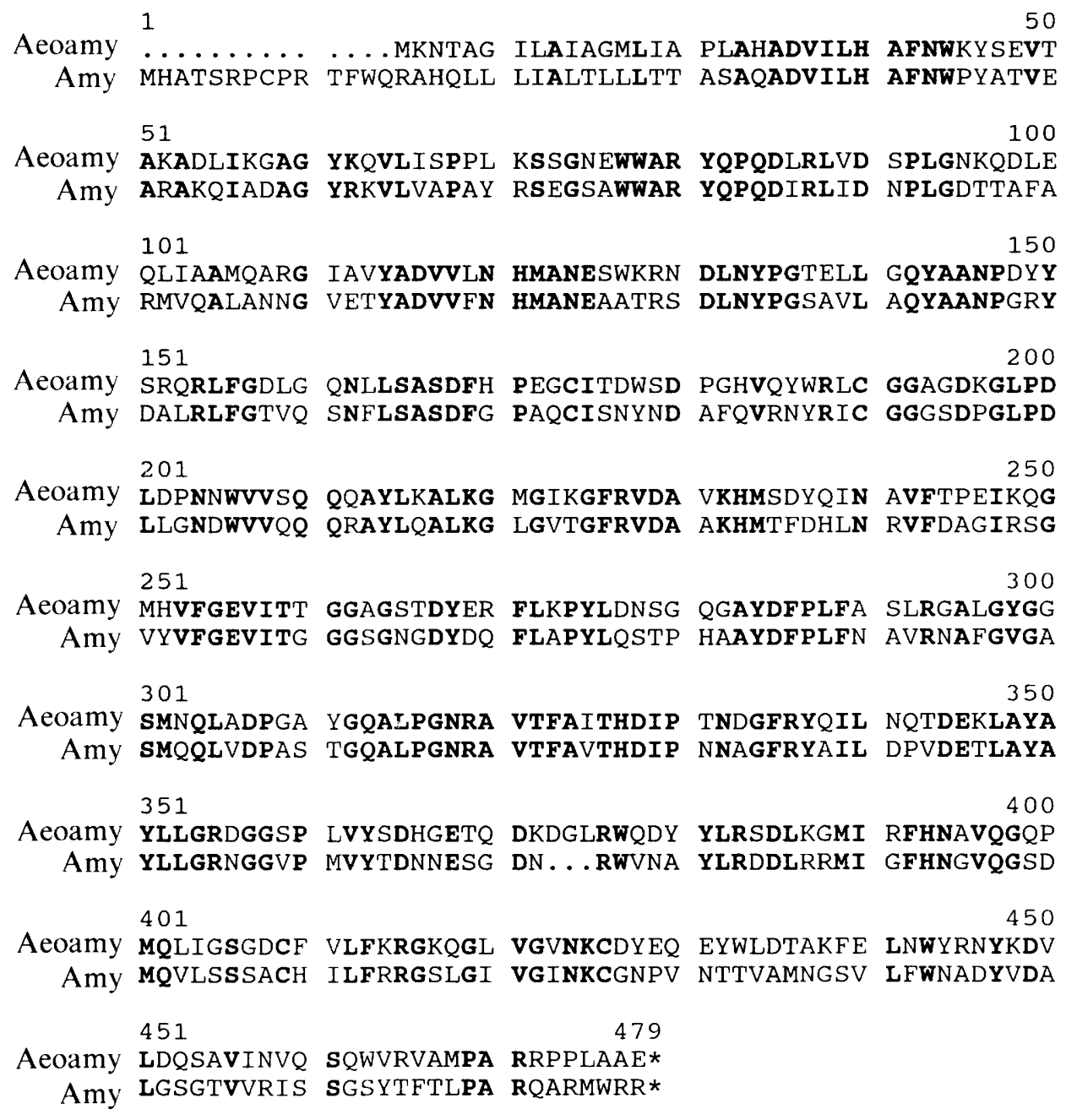

Fig. 4. Comparison between the amino acid sequence of $\alpha$-amylase of $X$. campestris pv. campestris (Amy) and that of $A$. hydrophila (Aeoamy). Identical amino acid residues are in bold type.

Table 2. Distribution of $\alpha$-amylase produced by $X$. campestris $p v$. campestris XC1701 and by E. coli $J M 101(p B 16)$

\begin{tabular}{cccc}
\hline \hline \multirow{2}{*}{$\begin{array}{c}\text { Bacterial } \\
\text { strains }\end{array}$} & \multicolumn{2}{c}{$\alpha$-Amylase activity [units (ml culture) ${ }^{-1}$ ] } \\
\cline { 2 - 4 } & Extracellular & Periplasmic & Cytoplasmic \\
\hline$X$. campestris pv. & 520.8 & $2 \cdot 2$ & $12 \cdot 3$ \\
campestris XC1701 & 0.5 & $2 \cdot 8$ & 0.8 \\
\hline E. coli $\mathrm{JM101}(\mathrm{pB} 16)$ & 0.5 &
\end{tabular}

Nucleotide sequence analysis of the amy gene

$\alpha$-Amylase activity was abolished by the deletion of $150 \mathrm{bp}$ from the right-hand BamHI site as shown in Fig. $2(c)$, indicating that the amy gene is located near the right end (as shown in Fig. $2 c$ ) of the $2.7 \mathrm{~kb}$ fragment. When a fragment extending from the BanII site to the righthand BamHI site was subcloned downstream of a $\mathrm{T} 7$ promoter, T7 RNA polymerase-driven transcription produced an $\alpha$-amylase of $45 \mathrm{kDa}$ in vivo (data not shown). The DNA sequence of this fragment revealed an ORF of 475 amino acids (Fig. 3). Location of the deletion mentioned above was determined and is marked in Fig. 3.

Nakajima et al. (1986) identified four conserved regions, while comparing the amino acid sequences of 11 different $\alpha$-amylases from a wide range of organisms. All these four regions exist in the putative $\alpha$-amylase amino acid sequence of $X$. campestris pv. campestris (Fig. 3). When the EMBL-GenBank Data Library was searched for homologous sequences, the $\alpha$-amylase of Aeromonas hydrophila (Gobius \& Pemberton, 1988) was found. Comparison of the two amino acid sequences showed $70 \%$ homology (Fig. 4). A signal sequence of 35 amino 


\begin{tabular}{|c|c|c|c|c|}
\hline (a) & Region 1 & Region 2. & Region 3 & Region 4 \\
\hline$X$. campestris & $\begin{array}{r}121 \\
\text { DVVfNH } \\
122\end{array}$ & $\begin{array}{r}233 \\
\text { GFevDAAKH } \\
210\end{array}$ & $\begin{array}{r}259 \\
\text { EVIt } \\
233\end{array}$ & $\begin{array}{r}328 \\
\text { FavtHD } \\
297\end{array}$ \\
\hline A. oryzae & $\begin{array}{r}\text { DVVaNH } \\
106\end{array}$ & $\begin{array}{r}\text { GlRiDtvKH } \\
238\end{array}$ & $\begin{array}{r}\text { EVID } \\
267\end{array}$ & $\begin{array}{r}\text { FevNHD } \\
331\end{array}$ \\
\hline B. stearothermophilus & $\begin{array}{r}\text { DVV } f D H \\
117\end{array}$ & $\begin{array}{r}\text { GFRLDAvKH } \\
208\end{array}$ & $\begin{array}{r}\text { Eyws } \\
244\end{array}$ & $\begin{array}{r}\text { FVDNHD } \\
306\end{array}$ \\
\hline Drosophila & $\begin{array}{r}\text { DVVfNH } \\
116\end{array}$ & $\begin{array}{r}\text { GFRvDAAKH } \\
213\end{array}$ & $\begin{array}{r}\text { EVID } \\
248\end{array}$ & $\begin{array}{r}\text { FVDNHD } \\
312\end{array}$ \\
\hline Mouse (pancreatic) & DaViNH & GFRLDAAKH & EVID & FVDNHD \\
\hline Consensus & DVVFNH & GFRLDAAKH & EVID & FVDNHD \\
\hline
\end{tabular}

(b)

\begin{tabular}{|c|c|c|c|}
\hline$X$. campestris & $\begin{array}{r}83 \\
\text { WWaRYQP } \\
80\end{array}$ & $\begin{array}{r}189 \\
\text { IsNYNDA fQVRNYRi } \\
169\end{array}$ & $\begin{array}{r}395 \\
\text { lRrMigFhNgVqG } \\
401\end{array}$ \\
\hline Drosophila & $\begin{array}{r}\text { WWERYQP } \\
79\end{array}$ & $\begin{array}{r}\text { IsNYNDAneVRNCEL } \\
174\end{array}$ & $\begin{array}{r}\text { IyNMVaFRNtVgs } \\
415\end{array}$ \\
\hline Mouse (pancreatic) & $\begin{array}{r}\text { WWERYQP } \\
79\end{array}$ & $\begin{array}{l}\text { IdNYNDAYQVRNCRL } \\
177\end{array}$ & $\begin{array}{l}\text { IRNMVaFRNVVNG } \\
418\end{array}$ \\
\hline Mouse (salivary) & $\begin{array}{r}\text { WWERYQP } \\
74\end{array}$ & $\begin{array}{r}\text { IENYqDAaQVRDCRL } \\
169\end{array}$ & $\begin{array}{r}\text { IRNMVaFRNVVNG } \\
410\end{array}$ \\
\hline Rat & $\begin{array}{r}\text { WWERYQP } \\
64\end{array}$ & $\begin{array}{r}\text { InNYNDAnQVRNCRL } \\
161\end{array}$ & $\begin{array}{r}\text { IRNMVAFRNVVNG } \\
403\end{array}$ \\
\hline Hog & $\begin{array}{r}\text { WWERYQP } \\
79\end{array}$ & $\begin{array}{r}\text { IESYNDPYQVRDCqL } \\
177\end{array}$ & $\begin{array}{r}\text { IRNMVWFRNVVDG } \\
418\end{array}$ \\
\hline Human (pancreatic) & $\begin{array}{r}\text { WWERYQP } \\
79\end{array}$ & $\begin{array}{r}\text { IENYNDATQVRDCRL } \\
177\end{array}$ & $\begin{array}{r}\text { IRNMVIFRNVVDG } \\
418\end{array}$ \\
\hline Human (salivary) & WWERYQP & IENYNDATQVRDCRL & IRNMVnFRNVVDG \\
\hline Consensus & WWERYQP & $\begin{array}{cc} & \mathrm{N} \\
\text { IENYNDA } & \text { QVRDCRL }\end{array}$ & $\begin{array}{cc}\text { N } \\
\text { IRNMV FRNVVDG }\end{array}$ \\
\hline
\end{tabular}

(c)

$X$. campestris

LAYAy lLgRngGvPmVy

393

B. amyloliquefaciens

LAYAF ILTRESGY PqVF

B. stearothermophilus

LAYAF ILTRqEGYPCVF

391

B. licheniformis

LAYAF ILTResGYPqVF

Consensus

LAYAFILTR GYP VF

Fig. 5. Comparison of the $\alpha$-amylase of $X$. campestris pv. campestris (a) with those of Aspergillus oryzae (Toda et al., 1982), B. stearothermophilus (Nakajima et al., 1985), Drosophila (Boer \& Hickey, 1986) and mouse (Hagenbuechle et al., 1980) in the four conserved regions (Nakajima et al., 1986); (b) with seven animal enzymes; and (c) with three Bacillus enzymes. The numbers above the last residues designate the locations of each region in each $\alpha$-amylase. Those amino acids appearing in over half of the compared sequences were taken as the consensus. A blank indicates absence of the consensus using the above criterion. Lower case letters represent unique sequences that are different from the consensus.

acids was predicted at the $\mathrm{N}$-terminus of the $\alpha$-amylase of $X$. campestris pv. campestris by the algorithm of von Heijne (1986).
The overall $\mathrm{G}+\mathrm{C}$ content of the BanII-BamHI fragment is $63.4 \%$, which is in good agreement with the high $\mathrm{G}+\mathrm{C}$ content of the DNA of $X$. campestris 
(Bradbury, 1984). Within the amy coding sequence, the third base of each codon exhibits a strong bias $(80 \%)$ toward $\mathrm{G}$ or $\mathrm{C}$, as is typical for coding sequences from organisms with high $\mathrm{G}+\mathrm{C}$ contents (Liu et al., 1990).

The predicted initiation codon is preceded with a likely ribosome-binding site, AGGAGA (Fig. 3). Located at 117 and 152 nucleotides upstream from the initiation codon, there is a putative - 10 sequence, TAGCAT, and a likely -35 sequence, TGCACA, respectively (Fig. 3). This promoter may not be efficiently recognized in $E$. coli, as the expression of $a m y$ in $E$. coli was enhanced by the upstream lac promoter or T7 promoter. An inverted repeat of 25 nucleotides was located four nucleotides downstream from the putative -10 region (Fig. 3). The location and the dyad symmetrical structure of this 25 nucleotide region resemble those of the lac operator (Watson et al., 1987). It was observed that the synthesis of $\alpha$-amylase in $X$. campestris pv. campestris was induced by starch or maltose (H.-F. Tsai, \& Y.-H. Tseng, unpublished results). This 25 bp inverted repeat may be involved in the negative regulation of amy gene expression in $X$. campestris pv. campestris.

\section{$N$-Terminal amino acid sequence of purified $\alpha$-amylase}

The extracellular $\alpha$-amylase of $X$. campestris pv. campestris was purified as described in Methods. The $\mathrm{N}$ terminal amino acid sequence was determined and is shown in Fig. 3 (underlined amino acid sequence). This result strongly suggested that the $\alpha$-amylase of $X$. campestris pv. campestris was processed at the predicted signal sequence processing site.

\section{Discussion}

We have cloned and expressed an amy gene of $X$. campestris pv. campestris in $E$. coli. The expressed $\alpha$ amylase activity was not likely to be that of $E$. coli, since (i) the E. coli host exhibited no detectable starchhydrolytic activity under our culture conditions (data not shown); (ii) the $\alpha$-amylase of $E$. coli has an apparent molecular mass of $66 \mathrm{kDa}$ (Freudlieb \& Boos, 1986), unlike the $45 \mathrm{kDa} \alpha$-amylase identified here; and (iii) the $\mathrm{N}$-terminal amino acid sequence of the processed protein predicted from the derived amino acid sequence of the cloned gene matched that of the extracellular $\alpha$-amylase purified from $X$. campestris pv. campestris.

The amino acid sequence derived from the nucleotide sequence of the amy gene of $X$. campestris pv. campestris not only showed the four regions highly conserved in eleven different prokaryotic and eukaryotic $\alpha$-amylases
(Nakajima et al., 1986), but also depicted $70 \%$ homology with the amino acid sequence of the $\alpha$-amylase of Aeromonas hydrophila (Gobius \& Pemberton, 1988). Furthermore, the postulated catalytic residues, Glu-230 and Asp-297, of Taka-amylase A of Aspergillus oryzae (Matsuura et al., 1984) are both conserved in the $\alpha$ amylase of $X$. campestris pv. campestris (Glu-256 and Asp-328 in Fig. $5 a$ ). In addition to the four conserved regions (Nakajima et al., 1986), comparisons of the $\alpha$ amylase of $X$. campestris pv. campestris with those of other organisms (as summarized in Figs $5 b$ and $c$ ) revealed three more regions, which were similar to those of animal enzymes (Hagenbuechle et al., 1980; MacDonald et al., 1980; Nakamura et al., 1984; Boer \& Hickey, 1986; Pasero et al., 1986), and one other region, which was similar to that of Bacillus amyloliquefaciens, Bacillus stearothermophilus and Bacillus licheniformis $\alpha$-amylases (Takkinen et al., 1983; Nakajima et al., 1985; Yuuki et al., 1985). Even though the $\alpha$-amylase of $X$. campestris pv. campestris is neither closely related to the animal nor to the Bacillus counterparts, it contained discrete conserved amino acid sequences from both categories.

Translocation of proteins across membranes occurs in both prokaryotes and eukaryotes. In the case of prokaryotic-transported proteins, the significance of the $\mathrm{N}$-terminal signal sequence in the translocation of periplasmic or outer membrane proteins is well recognized (Oliver, 1985; Randall et al., 1987). As to extracellular proteins of Gram-negative bacteria, it has been shown that the $\mathrm{N}$-terminal signal sequence is not sufficient to direct a protein across the outer membrane (Hirst \& Welch, 1988). Replacement with the signal sequence of an extracellular protein, the B subunit of $E$. coli enterotoxin, did not make $\beta$-lactamase leave the periplasm (Hirst \& Welch, 1988). The $\mathrm{N}$-terminal signal sequence of the amy gene predicted from the deduced amino acid sequence revealed all the characteristics of a typical signal sequence: a central hydrophobic region preceded by a positively charged $\mathrm{N}$-terminus and followed by a polar $\mathrm{C}$-terminus with a consensus processing site (Ala-X-Ala) (von Heijne, 1985). NTerminal amino acid sequence analysis of the exported $\alpha$ amylase showed that the precursor was indeed cleaved at the predicted processing site. These results suggest that processing of the $\mathrm{N}$-terminal signal sequence of this extracellular protein does not differ from those of envelope proteins. The appearance of $\alpha$-amylase activity in the periplasm of $E$. coli further supported the functional homology of the $\mathrm{N}$-terminal signal sequence of extracellular protein with those of periplasmic proteins of $E$. coli.

Like $X$. campestris pv. campestris, $A$. hydrophila is also Gram-negative and secretes $\alpha$-amylase extracellularly. Alignment of the two $\alpha$-amylase sequences exhibits a 
high degree of relatedness throughout. It is tempting to speculate that the high relatedness between the two $\alpha$-amylase sequences may reflect the conservation of sequences required for the secretion process, in addition to those required for enzyme activity. Such sequences indeed exist; for instance, the nine $\mathrm{N}$-terminal amino acids of the predicted mature protein are identical in both $\alpha$-amylases. However, in the absence of other molecular data to show the relatedness of the two microorganisms, one has to be cautious in making such a speculation.

The genes encoding two other extracellular enzymes, protease and endoglucanase, produced by $X$. campestris pv. campestris have been sequenced (Gough et al., 1990; Liu et al., 1990). Each deduced amino acid sequence predicted a potential $\mathrm{N}$-terminal signal sequence. However, comparison of the two amino acid sequences of the mature protein with that of the $\alpha$-amylase of $X$. campestris pv. campestris determined in this study did not reveal any consensus sequence. In studying the secretion of extracellular pullulanase by Klebsiella oxytoca, Pugsley et al. (1991) have recently demonstrated that the secretion intermediate, before it was translocated across the outer membrane, existed in a certain higher-ordered structure. This suggests that the signal(s) required for secretion across the outer membrane may not be one linear sequence of amino acid residues on the secreted protein, but could also involve some particular protein conformation.

The authors would like to thank W.-H. Hsu for his kind help in analysing the end products of hydrolysed starch, S.-T. Liu for his kind help in synthesizing primer, M.-F. Tam for analysing the N-terminal amino acid sequence of $\alpha$-amylase and $\mathrm{C}$. W. Chen for critical reading of the manuscript. This work was supported by reasearch grants from National Science Council of the Republic of China: NSC78-0203B005-04 to N.-T. Hu and NSC72-0409-B005-08 to Y.-H. Tseng.

\section{References}

Andro, T., Chambost, J.-P., Kotoujansky, A., Cattaneo, J., Bertheau, Y., Barras, F., van Gijsegem, F. \& Coleno, A. (1984). Mutants of Erwinia chrysanthemi defective in secretion of pectinase and cellulase. Journal of Bacteriology 160, 1199-1203.

Arber, W., Enquist, L., Hohn, B., Murray, N. E. \& Murray, K. (1983). Experimental methods for use with lambda. In Lambda II, pp. 433-466. Edited by R. W. Hendrix, J. W. Roberts, F. W. Stahl \& R. A. Weisberg. Cold Spring Harbor, NY: Cold Spring Harbor Laboratory.

BOER, P. H. \& HICKey, D. A. (1986). The $\alpha$-amylase gene in Drosophila melanogaster: nucleotide sequence, gene structure and expression motifs. Nucleic Acids Research 14, 8399-8411.

Bradbury, J. F. (1984). Genus II. Xanthomonas Dowson 1939, $187^{\mathrm{AL}}$. In Bergey's Manual of Systematic Bacteriology, vol. 1, pp. 199. Edited by N. R. Krieg \& J. G. Holt. Baltimore: Williams \& Wilkins.

Chu, S. T. \& Tseng, Y. H. (1981). Release of alkaline phosphatase from cells of Xanthomonas oryzae by manipulation of surface permeability. Chinese Journal of Microbiology and Immunology 14, 156-166.
Cohen, S. N., Chang, A. C. Y. \& Hsu, L. (1972). Non-chromosomal antibiotic resistance in bacteria: genetic transformation of Escherichia coli by R factor DNA. Proceedings of the National Academy of Sciences of the United States of America 69, 2110-2114.

Daniels, M. J., Barber, C. E., Turner, P. C., Cleary, W. G. \& SAWCZYC, M. K. (1984). Isolation of mutants of Xanthomonas campestris pv. campestris showing altered pathogenicity. Journal of General Microbiology 130, 2447-2455.

Dow, J. M., Scofield, G., Trafford, K., Turner, P. C. \& Daniels, M. J. (1987). A gene cluster in Xanthomonas campestris pv. campestris required for pathogenicity controls the excretion of polygalacturonate lyase and other enzymes. Physiological and Molecular Plant Pathology 31, 261-271.

Felmlee, T., Pellett, S., Lee, E.-Y. \& Welch, R. A. (1985). Escherichia coli hemolysin is released extracellularly without cleavage of a signal peptide. Journal of Bacteriology 163, 88-93.

Freudlieb, S. \& Boos, W. (1986). $\alpha$-Amylase of Escherichia coli, mapping and cloning of the structural gene, malS, and identification of its product as a periplasmic protein. Journal of Biological Chemistry 261, 2946-2953.

Frischauf, A. M., Lehrach, H., Poustka, A. \& Murray, N. (1983). Lambda replacement vectors carrying polylinker sequences. Journal of Molecular Biology 170, 827-842.

Gobius, K. S. \& Pemberton, J. M. (1988). Molecular cloning, characterization, and nucleotide sequence of an extracellular amylase gene from Aeromonas hydrophila. Journal of Bacteriology 170, 1325-1332.

Gough, C. L., Dow, J. M., KeEn, J., Henrissat, B. \& Daniels, M. J. (1990). Nucleotide sequence of the eng XCA gene encoding the major endoglucanase of Xanthomonas campestris pv. campestris. Gene 89, 53-59.

Gray, L., Mackman, N., Nicaud, J.-M. \& Holland, I. B. (1986). The carboxy-terminal region of haemolysin 2001 is required for secretion of the toxin from Escherichia coli. Molecular and General Genetics 205, $127-133$.

Hagenbuechle, O., Bovey, R. \& Young, R. A. (1980). Tissue specific expression of mouse $\alpha$-amylase genes: nucleotide sequence of isozyme mRNAs from pancreas and salivary gland. Cell 21, 179-187.

voN HeIJNE, G. (1985). Signal sequences: the limits of variation. Journal of Molecular Biology 184, 99-105.

vON HEIJNE, G. (1986). A new method for predicting signal sequence cleavage sites. Nucleic Acids Research 14, 4683-4690.

HENIKOFF, S. (1984). Unidirectional digestion with exonuclease III creates targeted breakpoints for DNA sequencing. Gene 28, 351-359.

HiRst, T. R. \& HolmgreN, J. (1987). Transient entry of enterotoxin subunits into the periplasm occurs during their secretion from Vibrio cholerae. Journal of Bacteriology 169, 1037-1045.

HiRST, T. R. \& WELCH, R. A. (1988). Mechanisms for secretion of extracellular proteins by Gram-negative bacteria. Trends in Biochemical Science 13, 265-269.

HoHN, B. \& MURRAY, K. (1977). Packaging recombinant DNA molecules into bacteriophage particles in vitro. Proceedings of the National Academy of Sciences of the United States of America 74, 3259-3263.

Holland, I. B., Blight, M. A. \& KenNy, B. (1990). The mechanism of secretion of hemolysin and other polypeptides from Gram-negative bacteria. Journal of Bioenergetics and Biomembranes 22, 473-491.

HOWARD, S. P. \& BUCKLEY, J. T. (1983). Intracellular accumulation of extracellular proteins by pleiotropic export mutants of Aeromonas hydrophila. Journal of Bacteriology 154, 413-418.

Hu, N.-T., Hung, M.-N., Chiou, S.-J., Tang, F., Chiang, D.-C., HuANG, H.-Y. \& Wu, C.-Y. (1992). Cloning and characterization of a gene required for the secretion of extracellular enzymes across the outer membrane by Xanthomonas campestris pv. campestris. Journal of Bacteriology 174, 2679-2687.

Liu, Y.-N., Tang, J.-L., Clakke, B. R., Dow, M. \& Daniels, M. J. (1990). A multipurpose broad host range cloning vector and its use to characterise an extracellular protease gene of Xanthomonas campestris pv. campestris. Molecular and General Genetics 220, 433-440.

MacDonald, R. J., Crerar, M. M., Swain, W. F., Pictet, R. L., Thomas, G. \& RutTer, W. J. (1980). Structure of a family of rat amylase genes. Nature, London 287, 117-122. 
Matsuura, Y., Kusunoki, M., Harada, W. \& Kakudo, M. (1984). Structure and possible catalytic residues of Taka-amylase A. Journal of Biochemistry 95, 697-702.

Messing, J. (1979). A multipurpose cloning system based on the singlestranded DNA bacteriophage M13. In Recombinant DNA Technical Bulletin, NIH Publication No. 79-99, vol. 2, no. 2, pp. 43-48.

Miller, J. H. (1972). Experiments in Molecular Genetics, pp. 431-434. Cold Spring Harbor, NY: Cold Spring Harbor Laboratory.

NaKajima, R., ImanaKa, T. \& AIBA, S. (1985). Nucleotide sequence of the Bacillus stearothermophilus $\alpha$-amylase gene. Journal of Bacteriology 163, 401-406.

Nakajima, R., ImanaKa, T. \& Aiba, S. (1986). Comparison of amino acid sequences of eleven different $\alpha$-amylases. Applied and Microbiological Biotechnology 23, 355-360.

Nakamura, Y., Ogawa, M., Nishide, T., Emi, M., Kosaki, G., Himeno, S. \& Matsubara, K. (1984). Sequences of cDNAs for human salivary and pancreatic $\alpha$-amylases. Gene 28, 263-270.

Nelson, N. (1944). A photometric adaptation of the Somogyi method for the determination of glucose. Journal of Biological Chemistry 153, 375-380.

NeU, H. C. \& HePpel, L. A. (1965). The release of enzymes from Escherichia coli by osmotic shock and during the formation of spheroplasts. Journal of Biological Chemistry 240, 3685-3692.

Oliver, D. (1985). Protein secretion in Escherichia coli. Annual Review of Microbiology 39, 615-648.

Pasero, L., Mazzei-Pierron, Y., Abadie, B., Chicheportiche, Y. \& Marchis-Mouren, G. (1986). Complete amino acid sequence and location of the five disulfide bridges in porcine pancreatic $\alpha$-amylase. Biochimica et Biophysica Acta 869, 147-157.

Pearson, W. R. \& LiPMAN, D. J. (1988). Improved tools for biological sequence comparison. Proceedings of the National Academy of Sciences of the United States of America 85, 2444-2448.

Pugsley, A. P., Poquet, I. \& Kornacker, M. G. (1991). Two distinct steps in pullulanase secretion by Escherichia coli K12. Molecular Microbiology 5, 865-873.

RANDAll, L. L., HaRdy, S. J. S. \& Thом, J. R. (1987). Export of protein : a biochemical view. Annual Review of Microbiology 41, 507541.

SANGer, R., Nicklen, S. \& Coulson, A. R. (1977). DNA sequencing with chain-terminating inhibitors. Proceedings of the National Academy of Sciences of the United States of America 74, 5463-5467.

Silhavy, T. J., Berman, M. L. \& EnQuist, L. W. (1984). In vitro packaging of DNA. In Experiments with Gene Fusions, pp. 173-176. Cold Spring Harbor, NY: Cold Spring Harbor Laboratory.

TAI, P. C., ZYK, N. \& CITRI, N. (1985). In situ detection of $\beta$-lactamase activity in sodium dodecyl sulfate-polyacrylamide gels. Analytical Biochemistry 144, 199-203.

Takkinen, K., Pettersson, R. F., Kalkkinen, N., Palva, I., SoEderlund, H. \& KAARIAINEN, K. (1983). Amino acid sequence of $\alpha$-amylase from Bacillus amyloliquefaciens deduced from the nucleotide sequence of the cloned gene. Journal of Biological Chemistry 258, $1007-1013$.

Toda, H., Kondo, K. \& Narita, K. (1982). The complete amino acid sequence of Taka-amylase A. Proceedings of the Japan Academy 58, 208-212.

TSENG, Y. H. \& PENG, K. C. (1985). Characterization of $\alpha$-amylase from phytopathogenic Xanthomonas campestris pv. campestris. Proceedings of the National Science Council Republic of China 9, 259268.

Vieira, J. \& Messing, J. (1982). The pUC plasmids, and M13mp7derived system for insertion mutagenesis and sequencing with synthetic universal primer. Gene 19, 259-268.

Watson, J. D., Hopkins, N. H., Roberts, J. W., Steitz, J. A. \& WEINER, A. M. (1987). Regulation of protein synthesis and function in bacteria. In Molecular Biology of the Gene, 4th edn, 465-502. California: The Benjamin/Cummings Publishing Company Inc.

Yuuki, T., Nomura, T., Tezuka, H., Tsubol, A., Yamagata, H., TsuKagoshi, N. \& UDAKA, S. (1985). Complete nucleotide sequence of a gene coding for heat- and $\mathrm{pH}$-stable $\alpha$-amylase of Bacillus licheniformis: comparison of the amino acid sequences of three bacterial liquefying $\alpha$-amylases deduced from the DNA sequences. Journal of Biochemistry 98, 1147-1156. 